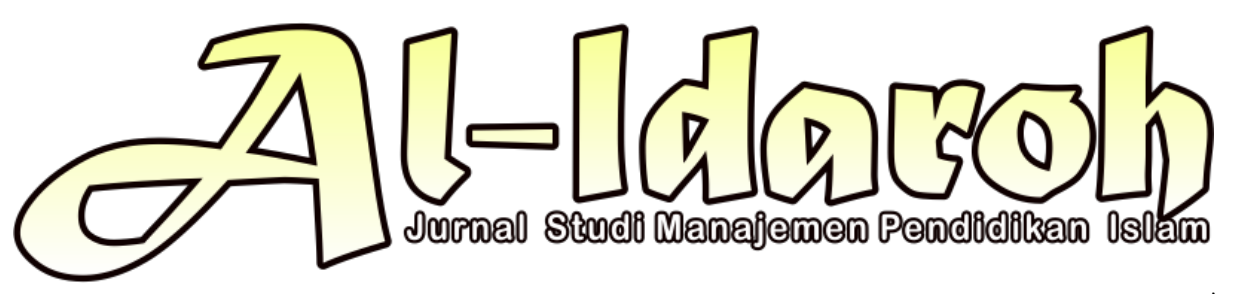

\title{
AKSIOLOGI ILMU PENGETAHUAN \\ MANAJEMEN PENDIDIKAN ISLAM
}

\author{
Didin Sirojudin \\ Universita KH. A. wahab Hasbullah Jombang \\ Email: mr.didinsirojudin@gmail.com \\ Hilyah Ashoumi \\ Universitas KH. A. Wahab Hasbullah Jombang \\ Email: hira@unwaha.ac.id
}

\begin{abstract}
Abstrak: Value always manifests together in actions or actions carried out by bumans whenever and wherever humans have needs, although it cannot be denied that sometimes the context of values is mostly wrapped in dialogical and dialectical uses of simple language which is difficult to philosophize. The problem is whether we are aware of it or not? actually we are discussing a value?. Questioning the benchmarks regarding the value, situation and status of the value, investigating the statement of an object and other possibilities related to the nature of value. Research on the axiology of Islamic education management science, the author examined using the library method or literature review, the goal is that the orientation of the values expected from the implementation of Islamic education management science can be known for its definition and benefits. The results of this study are the orientation of the values expected from the implementation of Islamic education management science itself is to embed leadership, managerial and organizational values into a personal soul that is stable, dynamic, independent and creative, so that in action it is always based on tangible Islamic characters. in several values, namely the value of worship, the value of benefit, the value of mercy (affection), the value of goodness, the value of long-term orientation, and submission to God.
\end{abstract}

Kata Kunci: Axiology, Values, Management of Islamic Education

\section{Pendahuluan}

Manusia merupakan makhluk sosial yang dianugerahi akal melalui akal tersebut manusia mampu berpikir tentang segala hal baik dalam segi cakupan materi maupun immateri, semuanya tidak luput menjadi objek yang dipikirkan. Melalui berpikir pula manusia mampu mengidentifikasi dan mendefinisikan semua objek materi yang ada di sekitarnya. menghimpun semua kebutuhannya, mengenal dan memahami betul akan identitas kemanusiaannya sampai pada tahap mengenal Tuhan sebagai sang kreator apa kehadirannya.

Al-Idaroh: Jurnal Studi Manajemen Pendidikan Islam

Volume 4 Nomor 2 September 2020; p-ISSN:2549-8339; e-ISSN: 2579-3683 


\section{Aksiologi Ilmu Pengetahuan Manajemen Pendidikan Islam}

Karena dianugrahi akal tersebut manusia menjadi istimewa. Lantas tidak sekadar cukup bangga, sehingga berdiam membatasi diri dengan objek lain yang ada di sekitarnya. Kreativitas dalam mengolah, mempertajam dan mengindikasikan kadar kapasitasnya sebagai anugrah adalah jalan untuk menumpas banalitas yang tak bertepi. Melalui akal pula, berabad-abad sebelum masehi manusia berusaha mencari hakekat arti. namun persoalan ini pun harus tergantikan dengan kemampuan masalah baru tentang identitas manusia sendiri. bahkan problematika ini di gada- gada kan sebagai persoalan yang lebih penting dari tanggapan sebelumnya. Dimana ada asumsi bahwa memahami dan mengenali diri pribadi manusia berarti ia memahami alam semesta. Termasuk didalamnya membahas tentang relasi manusia dengan objek sekitar. Hingga pada akhirnya memunculkan istilah yang disebut nilai, etika, dan estetika.

Mencermati setiap kausalitas eksistensi ojek materi menjadi tegukan pengetahuan. Tegukan pengetahuan yang menjadi asas akan adanya pengenalan khusus terhadap suatu objek tertentu, sehingga menghasilkan suatu definitip yang merupakan kesimpulan logis dari yang Nampak. Tidak dapat dipungkiri semuanya seakan-akan hanyut dalam rutinitas yang nampaknya tidak perlu dipertanyakan, nilaipun nampak sepele tanpa perlu pendefinisian. Padahal kita membutuhkan penjelasan yang kompleksitas dan totalitas mengenal mengenai pembahasan ini mengenai pembahasan nilai. Terlebih lebih bila kita mengingat bahwa semua aktivitas sehari-hari secara pasti tidak lepas dari pada nilai. Utama kita yang secara sadar telah berada dalam ruang lingkup lembaga pendidikan, kita dituntut perlu memahami aksiologi dalam ilmu Manajemen Pendidikan Islam.

Atas dasar demikian, nampaknya di sini pun kita membutuhkan pemahaman yang jelas mengenai persoalan aksiologi mulai dari yang mendasar, yakni dalam ruang lingkup kehidupan sehari-hari sampai dengan mengaplikasikan aksiologi dalam ilmu pengetahuan manajemen pendidikan Islam.

\section{Metode Penelitian}

Penelitian ini tergolong penelitian pustaka atau literer, maka penelitian ini menggunakan pendekatan kualitatif, yaitu penelitian yang tidak mengadakan perhitungan data secara kuantitatif. Penelitian ini bersifat menyeluruh (holistik), 
dengan memandang bahwa keseluruhan sebagai suatu kesatuan yang lebih penting daripada satu-satu bagian. Karena diharapkan dapat diperoleh data-data deskriptif, yaitu data-data mengenai Aksiologi Ilmu Pengetahuan Manajemen Pendidikan Islam. Sumber data yang diambil dari penelitian ini adalah sumber data primer dan sekunder.

\section{Pembahasan}

1. Pengertian Aksiologi

Secara simplikasi term Aksiologi memiliki makna menunjukkan kata sifat, artinya bersifat Aksiologi. Menurut etimologi axiologi adalah berasal dari bahasa yunani kuno yakni aksios dan logos, aksios arinya nilai sedangkan logos memiliki arti teori, sehingga aksiologi diartikan teori yang mempelajari nilai, ${ }^{1}$ yang merupakan cabang dari filsafat.Sedangakan suriasumantri menjelaskan bahwa aksiologi ialah teori nilai yang ada kaitannya untuk sebuah manfaat dari pengetahuan yang di dapat ${ }^{2}$.Dalam perspektif Lorens Bagus terminologi Aksiologi ditegaskan berasal dari kata yunani, yakni axios yang berarti layak, pantas dan logos yang bermakna ilmu, studi mengenai dari akar kata ini terfokus menjadi tiga definitif yang signifikan

Pertama, Aksiologi diartikan sebagai analisis nilai-nilai. Dalam artian melelui analisis ini bertujuan membatasi arti, ciri-ciri asal tipe kriteria dan status epistemiologi dari nilai-nilai tersebut. Kedua Aksiologi memiliki arti sebagai suatu studi yang menyangkut segala yang bernilai atau studi yang menyangkut teori umum tentang nilai sementara dalam pengertian yang Ketiga Aksiologi merupakan studi filosofis mengetahui mengenai hakikat nilai-nilai. ${ }^{3}$

Tidak jauh berbeda dengan pengertian dalam kamus ilmiah populer yang menegaskan Aksiologi lebih sarkastik dan universal. Dimana Aksiologi bermakna penyelidikan terhadap nilai-nilai atau martabat dan tindakan manusia (cabang dari filsafat). ${ }^{4}$ Berisikan dan terikat dengan definisi yang telah dipaparkan di atas, Louis

${ }^{1}$ Uyoh Sadulloh, Pengantar Filsafat Pendidikan, (Bandung: Penerbit Alfabeta, 2007), 36

2 Jujun S. Sumantri. Filsafat Ilmu : Sebuah Pengantar Populer. (Jakarta : 2005, Sinar Harapan), 17

${ }^{3}$ Lorens Bagus, Kamus Filsafat. (Jakarta: PT. Gramedia Pustaka Utama, 2002), 33

${ }^{4}$ Pius A Partanto dan M. Dahlan Al Barry, kamus Ilmiah Populer, (Surabaya: Arkola,2001), 23 


\section{Aksiologi Ilmu Pengetahuan Manajemen Pendidikan Islam}

O. Kattsoff menyatakan bahwa Aksiologi merupakan ilmu pengetahuan yang menyelidiki hakikat nilai, yang umumnya ditinjau dari sudut pandang kefilsafatan. ${ }^{5}$

Dari semua pandangan tersebut setidaknya kita telah mampu mendeskripsikan dan mengambil benang merah mengenai term Aksiologi. Bahwa Aksiologi merupakan salah satu cabang filsafat yang memiliki fokus kajian dalam menganalisis hakikat nilai atau segala hal yang bersangkut paut dengan nilai.

2. Persoalan Aksiologi Dalam Kehidupan Sehari-Hari

Mengenal diri sama halnya dengan mengetahui cara memperoleh pengetahuan Mengenal diri berarti mengetahui jiwa dan hidup lebih tegas dan berpijak pada persoalan ke susilaan yang senantiasa mengarah dan mencari hakikat yang baik (yang bersifat hakiki). ${ }^{6}$ Harus di garis bawahi, bahwa persoalan hakikat yang baik ini mengejewantah sebagai embrio filsafat nilai. bahkan tidak jarang pula dapat kita temukan persoalan hakikat yang baik ini disandingkan dengan masalah nilai.

Masalah hakikat yang baik dan nilai sudah barang tentu akan sangat kentara kita jumpai dalam rumpun sosial, terlebih lebih manusia yang memiliki indra dan akal senantiasa melakukan interaksi dan hubungan-hubungan korelasi ini pula yang memberi makna terhadap yang baik dan nilai. baik itu dengan benda yang sering disebut dengan objek fisik maupun dengan sesama manusia sendiri yang terkadang sering memiliki posisi sebagai subjek, begitu halnya tatkala melaksanakan persoalan Aksiologi dalam kontinuitas kehidupan sehari-hari. sejatinya hakikat yang baik merupakan bagian nilai yang tidak dapat dipisahkan dari eksistensinya, sebab nilai justru selalu diperbincangkan dalam skala rentan waktu yang tidak terbatas, entah itu tatkala dalam perjalanan, di warung kopi, di lembaga pendidikan, di lembaga institusi bahkan dalam ruang lingkup yang bersifat privasi sekalipun dan di tempat-tempat lain sebagainya.

Berkorelasi dengan persoalan nilai peribahasa latin menyebutkan masalah selera tidak dapat diperdebatkan (de gustibus non disputandum). Hal ini menunjukkan bahwa nilai memiliki ciri khas yang istimewa yakni bersifat mendalam dan

\footnotetext{
${ }^{5}$ Louis O. Kattsoff, Pengantar Filsafat, terj. Soejono Soemargono, (Yogyakarta: Tiara Wacana Yogya,2004),Hal.319

${ }^{6}$ Louis O. Kattsoff, Pengantar Filsafat....., 317
} 
langsung berasal dari penilaian, namun apabila sepakat demikian berarti serta merta kita menyetujui bahwa nilai bersifat individual yang tidak dapat dibantahkan dan diperdebatkan, bukankah justru ini akan bermuara pada timbulnya kompleks yang sangat nyata dan tidak dapat dihindarkan, sebab tidak ada patokan nilai yang diberlakukan. $^{7}$ Yang terjadi justru mengutamakan rutinitas perilaku yang menunjukkan kesusilaan yang bersifat pribadi sekaligus mencerminkan silogisme yang berupa proposisi subjektivitas. Jika demikian, yang menjadi persoalan ialah nilai itu objektif atau subjektif.?

a. Nilai Itu Objektif Atau Subjektif

Permasalahan mendasar dalam usaha mendefinisikan dan memahami nilai adalah mencari tahu akar ataupun sumber kemunculan dari nilai tersebut, apakah benar sesuatu itu memiliki nilai manakala manusia mendapatkannya? Menginginkannya? Apakah sebab ada hasrat kenikmatan dan kebaikan yang dikandungnya, lantas kita memberikan penilaian penilaian terhadap objek? atau mungkin malah sebaliknya justru objek tersebut memiliki nilai bawaan (mendahului kenyataan) yang sama sekali asing bagi psikologis kita? Simplikasinya nilai itu apakah objektif atau subjektif?

Untuk sekadar penganalogian, dimisalkan suatu objek fisik memiliki dua kualitas, yakni kualitas primer dan sekunder jenis kualitas yang pertama merupakan kualitas yang melekat pada diri objek untuk lebih mudah sebut saja objek bawaan dari objek, sementara jenis kualitas yang kedua adalah kualitas yang digantungkan kepada persepsi subjek. setidaknya pengandaian tersebut bermuara pada pemahaman sebagai berikut:

Pertama, pandangan objektif. Kelompok objektif meyakini bahwa nilainilai adalah kenyataan yang tidak terikat oleh ruang dan waktu sehingga dapat dikatakan bahwa nilai-nilai merupakan esensi esensi logis yang dapat diketahui akal (objektifisme logis). Disisi yang lain, terdapat pula pandangan bahwa nilainilai merupakan unsur-unsur objektif yang menyusun kenyataan. sebut saja pandangan ini dengan istilah objektifme metafisik. paham objektif ini sama

\footnotetext{
${ }^{7}$ Risieri Prondizi, Pengantar Filsafat Nilai, trj. Cut Ananta Wijaya, Cet. 11, (Yogyakrta: Pustaka Pelajar, 2011), 17
} 


\section{Aksiologi Ilmu Pengetahuan Manajemen Pendidikan Islam}

sekali tidak menggantungkan diri pada pengalaman subjek. sebab nilai identitas bawaan yang akan memperkenalkan diri kepada manusia. ${ }^{8}$

Kedua pandangan subjektif. Ditinjau dari sudut pandangan ini nilai merupakan suatu bentuk reaksi yang diberikan oleh manusia sebagai pelaku tahu subjek yang keberadaannya tergantung pada pengalaman-pengalaman (ruang lingkup empiris). Paham ini meyakini bahwa kualitas mampu melukiskan suatu objek berlandaskan pengalaman panca indra, seolah-olah semua objek telah bertolak pada imajinasi, khayalan tentang objek telah tersimpan akut dalam kesan indrawi melalui pengalaman. Maka nilai ini pun diproyeksikan sebagai kualitas empiris yang dapat dirasakan melalui indra namun tidak bentuk kehadirannya tidak dapat didefinisikan.

Persoalannya kehadiran nilai tidak bisa lepas dari adanya penilaian sehingga apakah mungkin nilai akan memiliki makna tanpa pertimbangan penilaian sebagai apresiasi manusia? bagaimanakah cara menilai ini menanggung identitas dirinya apabila adanya di luar lingkup penilaian manusia.? Nampaklah sedikit kelemahan dari pandangan objektif terhadap nilai, mungkin ada benarnya apa yang nyatakan subjektif, bahwa nilai mendahului penilaian. Dapat dikatakan pendekatan subjektif adalah proses pemahaman nilai. Nampaknya sangatlah menjadi benar apabila subjektif mendasarkan diri pada pengalaman. meskipun pada tahapan dan situasi tertentu akan terjadi perbedaan dalam menafsirkan atau memahami pengalaman. ${ }^{10}$

Tidak sampai disana pandangan objektif juga berusaha memberikan jawaban bahwa penilaian yang mendasarkan diri pada pengalaman indra tersebut sesungguhnya tidaklah berlaku bagi mereka yang mempunyai indra tidak sempurna sejak lahir sehingga nampaknya mereka pun akan sulit menerima apabila nilai disebut sebagai kualitas empiris justru sebaliknya yang ada adalah kenyataan objektif.

${ }^{8}$ Louis O. Kattsoff, Pengantar Filsafat 323

${ }^{9}$ Lorens Bagus, Kamus Filsafat...., 33

${ }^{10}$ Risieri Prondizi, Pengantar Filsafat Nilai......, 25-27 
b. Alternatif Untuk Meninjau Persoalan

Pertentangan antara pandangan objektif it as dan subjektivitas tidak kunjung reda, bahkan dialog antara kedua paham tersebut lebih nampak sebagai suatu perputaran lingkaran yang statis sehingga membuat kita tidak dapat berpihak pada satu pandangan tertentu sebab dari itu satu posisi menuju posisi yang lain kemudian kembali lagi pada posisi yang pertama hal ini terjadi karena beberapa kemungkinan entah itu karena fakta persoalan yang kurang baik yakni dengan mengharuskan ya untuk memilih antara nilai itu objektif atau subjektif atau mungkin disebabkan oleh kekacauan hasrat untuk mereduksi seluruh unsur yang ada menuju suatu unsur yang cenderung bersifat hakiki hal inilah yang menuntut kita untuk fokus pada satu aspek belaka.

Sebagai alternatif untuk lepas dari kekacauan tersebut maka ada kemungkinan kita dapat meninjau persoalan realitas kehidupan sehari-hari dengan mengkaji hirearki nilai yang berbeda-beda berusaha memahami kualitas nilai ih yang berakhir akik dari yang paling rendah sampai yang paling tinggi di mulai dari kualitas nilai rendah misalnya saja dengan menikmati segelas anggur di manakah letak kualitas nilai bagi dia yang meminumnya maka akan mengatakan bahwa nikmat itu adalah milik anggur berbeda lagi apabila dibandingkan dengan minuman yang lain tentu bagi mereka yang tidak suka anggur penilaian akan bersifat subjektif penolakan terhadap kenikmatan anggur itu bukan berarti karena rendahnya suara bukan pula kata rusaknya selera seseorang sebab hal ini dapat karena kan tradisi dan kebiasaan selera yang berbeda sehingga dapat dikatakan bahwa selera merupakan pengakuan nilai subjektif yang lebih menonjol di atas objektif nilai subjektif inilah yang merupakan pengakuan kualitas yang paling rendah dalam tataran aksiologi. ${ }^{11}$

Namun sisi kemenonjolan tersebut akan sirna kepada tataran axioo logis yang lebih tinggi. misalnya saja pada nilai etis pemberian keputusan atau pengadilan tidak dipengaruhi oleh psikologis, kondisi yang tidak mengikuti isi hati, disinilah akan nampak sisi objektifitas yang sangat besar. Diantara kedua nilai di atas orang dapat pula menemukan nilai yang lain yakni kegunaan vital

${ }^{11}$ Risieri Prondizi, Pengantar Filsafat Nilai....., 32-33 


\section{Aksiologi Ilmu Pengetahuan Manajemen Pendidikan Islam}

dan estetika. Namun Nilai estetik memiliki kualitas yang tinggi, sehingga tidak menutup kemungkinan adanya kolaborasi antara nilai objektifitas dan subjektivitas.

c. Persoalan Metodologis

Kontradiksi dan kebulatan yang terjadi antara kaum objektif dan subjektif mengenai nilai sejatinya bukan hanya mendasarkan pada sumber dan kualitas dari nilai tersebut, melainkan terletak pula pada kejelasan metodologi yang digunakan sebagai pijakan yakni memberi prioritas pada persoalan metode dan kriteria apa yang paling tepat untuk menentukan hakikat nilai, sebagaimana dalam pandangan john dewey bahwa persoalan nilai yang paling menentukan ialah persoalan metodologi, sebab hanyalah sia-sia apalah apabila aksiologi tersebut menyadari diri tanpa diiringi dengan menjernihkan metode. ${ }^{12}$

Sebagaimana halnya semangat Furirifikasi ilmu pada abad ke 16 sampai 18 masehi, Rasio empiris berlomba-lomba menampilkan fenomena yang nampak sekaligus menghindari yang bersifat metafisik. Begitu juga dengan metode yang seharusnya diketengahkan dalam menelisik hakikat nilai. Telah disebutkan di atas bahwa ada dua aliran besar yang ditawarkan, yakni objektivtas yang beraliran apriori dengan melibatkan institusi emosional (keintiman esensi dan keyakinan) dan intuisi yang sempurna (mengutamakan esensi), tokoh yang masyhur dalam hal ini ialah Max Scheler. Sementara subjektifitas bercorak empiris dengan menjadikan pengalaman indra sebagai pijakan dalam mempersoalkan nilai. ${ }^{13}$

Selain itu, penggunaan kriteria menurut kesepakatan adalah hal penting untuk menentukan salah atau benarnya teori maupun hipotesis sebab kokohnya pengetahuan ilmiah berpijak pada kriteria kriteria tertentu sebagai ukuran, setidaknya tatkala kita berpijak pada metode dan kriteria yang jelas tidak akan timbul skeptifisme.

\footnotetext{
${ }^{12}$ Bertand Russel, Sejarah Filsafat Barat dan kaitannya dengan Kondisi Sosio-Politik dari Zaman kuno hingga sekarang, (Yogyakarta: pustaka pelajar,2007), 170-175

${ }^{13}$ Risieri Prondizi, Pengantar Filsafat Nilai....., 36-37
} 


\section{d. Memahami Nilai}

Untuk memahami nilai kita dituntut terlebih dahulu memahami keberadaan nilai nampaknya sudah jelas di muka bahwa nilai tidak dapat menopang dirinya sendiri melainkan keberadaan nilai bersifat parasit terletak pada pengembang yang riel, misalnya saja pohon batu kanvas dan lain sebagainya. pengemban inilah yang dapat di persepsi indra yang mencangkok bentuk, dari bentuk objek riel melalui pikiran. Masalahnya apakah kita benarbenar melalui indra dalam rangka mempersepsi pengembangan (objek riel dalam nilai) dan nilai? Apakah mungkin secara bersamaan antara wahana nilai (objek real) yang dinilai di persepsi dengan cara yang sama?

Menurut Max Scheler nilai menyatakan diri melalui intuisi emosional, sebab intuisi emosional bersifat akurat tanpa adanya pengalaman yang mendahului dan mengemban yang sesuai misalnya saja dia menulis, maka nilai suatu benda telah tersedia secara jelas dan tegas meski tanpa adanya penambahan yang menyatakan diri kepada indra kita.

Konsep nilai Max Scheler adopsi dan disebar luas kan oleh jos Ortega y Gasset di spanyol pada tahun 1923, ia menyatakan bahwa pengalaman tentang nilai sama sekali tidak tergantung pada pengalaman tentang benda. pengalaman sejatinya memiliki jenis benda, objek, realitas hakekatnya adalah bersifat buram dalam persepsi. seburam kita ingin melihat sebutir bagian dari keseluruhan buah apel. sementara bagi objek yang tidak ril, semisal bilangan segitiga, konsep, satu nilai memiliki substansi yang bersifat transparan, dalam arti keseluruhan nya dapat dilihat sekaligus. ${ }^{14}$

Nampaknya harus dipahami pula bahwa pemahaman tidak selamanya bersifat definitive, justru dengan menggunakan berbagai pendekatan baru akan menimbulkan kejutan baru. berbeda halnya dengan persoalan etika yang dapat dikatakan jauh lebih rumit, sebab hakikat nilai terkadang tidak nampak pada kesan pertama. Hal ini dikarenakan intuisi nilai perspektif yang diasumsikan diarahkan pada sifat emosional, terlebih persoalannya akan sangat menonjol lagi dalam persoalan estetika, namun hal ini terletak tidak terjadi pengurangan

${ }^{14}$ Risieri Prondizi, Pengantar Filsafat Nilai....., 43-44 


\section{Aksiologi Ilmu Pengetahuan Manajemen Pendidikan Islam}

unsur intelektual yang membantu pemahaman kita. Begitu halnya apabila kita berangkat dari tarap estetika menuju tarap etis legal kehadirannya unsur rasional tidak dapat ditolak. ${ }^{15}$

Dapat dikatakan bahwa dalam ruang lingkup aksiologi akan mengunggulkan kegunaan, intelektualitas dan secara sekaligus menyisihkan emosional, adanya konsep pendahuluan tentang tujuan yang harus dicapai dan cara yang harus digunakan untuk mencapai merupakan cara untuk memahami kegunaan objek. ${ }^{16}$ Tidak dapat dipungkiri pula, setelah kita memahami nilai secara penuh dan secara intuitif, perselisihan mengenai intuisi yang kontradiksi adalah masalah yang tidak dapat dihindari, namun semuanya akan dapat teratasi tatkala kita memahami arti secara mendalam dan segala bentuk kerumitan yang kompleks tentang nilai.

3. Aksikologi Ilmu Pengetahuan Manajemen Pendidikan Islam

Sementara diskursus aksologi ilmu pengetahuan dalam manajemen pendidikan islam selalu merasakan pada implikasi tujuan dan manfaat dari adanya kegiatan perencanaan, pengorganisasian, pelaksanaan, pengawasan dan penilaian dalam suatu mencapai efektivitas dalam suatu pendidikan Islam. ${ }^{17}$ Atas dasar Pendefinisian tersebut dapat dipahami bahwa nilai dalam ilmu pengetahuan manajemen pendidikan islam memiliki dua kecenderungan yakni, nilai secara teoritis ilmu pengetahuan dan nilai secara praktis.

Pertama nilai secara teoritis, Di satu sisi manajemen pendidikan islam sebagai ilmu pengetahuan mampu menghadirkan kaidah-kaidah tertentu yang membentuk keindahan teori. Teori pembelajaran yang membuat pola-pola perencanaan, pengorganisasian, pelaksanaan, pengawasan dan upaya penilaian yang bersifat khusus dan sistematis ilmu pengetahuan yang berasaskan pada teori etika estetika dan moral karakter Islam. seperti halnya konsep etika islam (Akhlak) yang digagas oleh ibnu miskawai, yang dijadikan landasan umum dalam adanya tarbiyah al akhlak dalam pendidikan islam, selanjutnya ketiga unsur tersebut (etika, estetika dan moral) dielaborasi ke dalam konsep sistem dan metodologi dalam

\footnotetext{
${ }^{15}$ Risieri Prondizi, Pengantar Filsafat Nilai.....,.43

${ }^{16}$ Risieri Prondizi, Pengantar Filsafat Nilai.....,.44

${ }^{17}$ Sri Suminar, Tinjauan Filsafat (Ontologi, Epitimologi, dan Aksiologi dalam Manajemen pembelajaran Berbasis Teori Sibernetik), dalam Jurnal Edukasi. Vol.6, No.3, Juni,2012, 2.
} 
pembelajaran manajemen pendidikan islam yang kemudian menuntutnya untuk diimplementasikan dalam wujud praktis. ${ }^{18}$

Sementara kedua, nilai secara praktis dalam artian tindakan yang bersifat subjektif. melibatkan peran subjek dalam mengkostruk hadirnya satu pendidikan islam seperti halnya yang kita ketahui bahwa dalam pendidikan sendiri pada umumnya deterministik menguji dan mengintegrasikan semua nilai, mulai dari tindakan moral, nilai ekspresi keindahan, estetika dan nilai sosial politik dalam kehidupan manusia dan termasuk mengeja wanita akan menjadi kepribadian anak.19 Atau dapat pula secara sederhana kita katakan bahwa tujuan pendidikan adalah internallisasi nilai-nilai budaya islam ke dalam jiwa anak didik, Meskipun demikian, akan tetapi nilai-nilai kebenaran keindahan, kebaikan dan religiusitas di sini berlaku dalam ruang lingkup pendidik, peserta didik dan lingkungan sekitar.

Dapat kita garis bawahi bahwa pada tahapan praktis ini, nilai-nilai yang nampak telah berubah hasil, dampak dan konsekuensi yang sesuai dengan perencanaan, pengorganisasian, pengawasan dan penilaian telah diekspektasikan sehingga pada akhirnya akan membentuk mentalitas sikap dan kesadaran dalam perilaku, baik itu subjek yang berperan sebagai pendidik yang membuat sistem manajemen tersebut ataupun peserta didik yang berperan sebagai objek yang terikat sistem kontrol manajemen pendidikan islam tersebut.

Adapun orientasi nilai-nilai yang di ekspektasikan dari implementasi ilmu pengetahuan manajemen pendidikan islam sendiri ialah membubuhkan nilai-nilai kepemimpinan, managerial dan organisator kedalam jiwa pribadi yang mantap dinamis mandiri dan kreatif. ${ }^{20}$ Sehingga dalam tindakannya selalu berpijak pada karakter Islami yang berwujud dalam beberapa nilai sebagai berikut:

\footnotetext{
${ }^{18}$ Sri Soeprapto, Landasan Aksiologi Sistem Pendidikan Nasional Indonesia dalam Perspektif Filsafat Pendidikan, dal Jurnal Cakrawala pendidikan. Vol.4, No.2, Jumi, 2012, 2-3

${ }^{19}$ Sri Suminar, Tinjauan Filsafat...hal.4

${ }^{20}$ Moh. Wardi, Problematika Pendidikan islam dan Solusi Alternatifnya (Perspektif ontologis, Epitemologis dan Aksiologis), dalam Jurnal Tadris, Vol.8, No.1, Juni,2013, hal.65-67
} 
1. Nilai ibadah dalam setiap proses bertindak dan berpikirnya selalu menghadirkan allah sebagaimana firman allah dalam surat al imron ayat 191

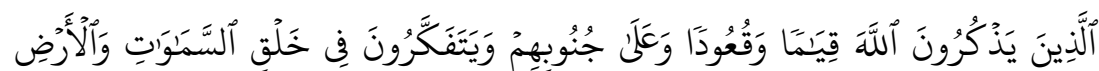

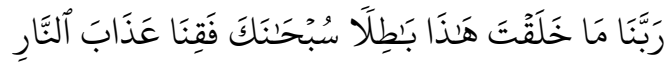

Arinya: (yaitu) orang-orang yang mengingat Allah sambil berdiri atau duduk atau dalam keadan berbaring dan mereka memikirkan tentang penciptaan langit dan bumi (seraya berkata): "Ya Tuban Kami, Tiadalah Engkau menciptakan ini dengan sia-sia, Maha suci Engkau, Maka peliharalah Kami dari siksa neraka. (Q.S Ali Imron Ayat: 191)

2. Nilai Ikhsan, tujuan dan dampak dari terus selenggarakannya manajemen pendidikan islam selalu memperhatikan sisi manfaat kemanusiaan, maslahat untuk orang lain sebagaimana firman Allah SWT:

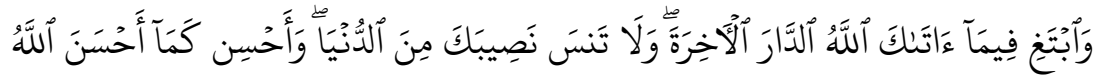

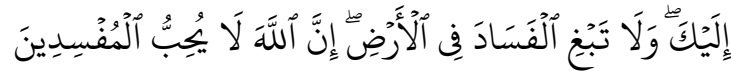

Artinya: dan carilah pada apa yang telah dianugerabkan Allab kepadamu (kebahagiaan) negeri akhirat, dan janganlah kamu melupakan bahagianmu dari (kenikmatan) duniawi dan berbuat baiklah (kepada orang lain) sebagaimana Allah telab berbuat baik, kepadamu, dan janganlah kamu berbuat kerusakan di (muka) bumi. Sesunggubnya Allah tidak menyukai orang-orang yang berbuat kerusakan. (Q.S.Al Qashas: 77)

3. Nilai masa depan sebagaimana firman Allah SWT.

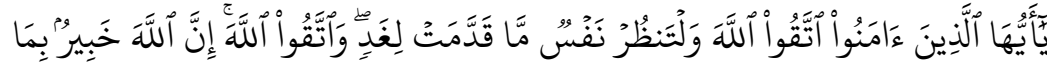

$$
\begin{aligned}
& \text { تَعْمَلُونَ }
\end{aligned}
$$

Artinya : Hai orang-orang yang beriman, bertakwalah kepada Allah dan bendaklah Setiap diri memperhatikan apa yang telah diperbuatnya untuk. bari esok (akbirat); dan bertakwalah kepada Allah, Sesunggubnya Allah Maha mengetahui apa yang kamu kerjakan (Q.S Al Hasyr: 18)

4. Nilai kerahmatan sebagaimana firman Allah SWT.

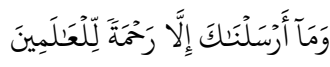

Artinya: Dan Tiadalah Kami mengutus kamu, melainkan untuk (menjadi) rahmat bagi semesta alam. (Q.S Al Anbiya Ayat: 107)

Sederhananya nilai-nilai yang terdapat dalam ilmu pengetahuan manajemen pendidikan islam hendak mengusung Semangat humanis properti dan analitis. 


\section{Kesimpulan}

Aksiologi merupakan salah satu cabang filsafat yang memiliki fokus kajian dalam menganalisis hakikat nilai atau segala hal yang bersangkut paut dengan nilai. Orientasi nilai-nilai yang di ekspektasikan dari implementasi ilmu pengetahuan manajemen pendidikan islam sendiri ialah membubuhkan nilai-nilai kepemimpinan, managerial dan organisator kedalam jiwa pribadi yang mantap dinamis mandiri dan kreatif, Sehingga dalam tindakannya selalu berpijak pada karakter islami yang berwujud dalam beberapa nilai, yakni Pertama, nilai Ibadah dalam setiap proses bertindak dan berpikirnya selalu menghadirkan allah, Kedua, nilai ikhsan tujuan dan dampak dari terus selenggarakannya manajemen pendidikan islam selalu memperhatikan sisi manfaat kemanusiaan, Ketiga, nilai masa depan yang sesungguhnya masa depan manusia adalah akhirat. Keempat, nilai kerahmatan (kasih sayang), Kelima, nilai kebaikan, Keenam, nilai orientasi jangka panjang, dan Ketujuh, berserah diri kepada Tuhan.

\section{Daftar Rujukan}

Bagus. Lorens, Kamus Filsafat, Jakarta: PT. Gramedia Pustaka Utama, 2002.

Kattsoff. Louis O., Pengantar Filsafat, terj. Soejono Soemargono, Yogyakarta: Tiara Wacana Yogya, 2004.

Partanto. Pius A dan Barry. M. Dahlan Al, Kamus Ilmiah Populer, Surabaya: Arkola, 2001

Prondizi. Risieri, Pengantar Filsafat Nilai, trj. Cut Ananta Wijaya, Cet. 11, Yogyakrta: Pustaka Pelajar, 2011.

Russel. Bertand, Sejarah Filsafat Barat dan kaitannya dengan Kondisi SosioPolitik dari Zaman kuno hingga sekarang, Yogyakarta: pustaka pelajar,2007.

Sadulloh. Uyoh, Pengantar Filsafat Pendidikan, Bandung: Penerbit Alfabeta, 2007.

Soeprapto Sri, Landasan Aksiologi Sistem Pendidikan Nasional Indonesia dalam Perspektif Filsafat Pendidikan, dal Jurnal Cakrawala pendidikan. Vol.4, No.2, (2012).

Sumantri. Jujun S, Filsafat Ilmu : Sebuah Pengantar Populer, Jakarta : 2005, Sinar Harapan), 17 
Suminar. Sri, Tinjauan Filsafat (Ontologi, Epitimologi, dan Aksiologi dalam Manajemen pembelajaran Berbasis Teori Sibernetik), Jurnal Edukasi. Vol.6, No.3, (2012).

Wardi. Moh., Problematika Pendidikan Islam dan Solusi Alternatifnya (Perspektif ontologis, Epitemologis dan Aksiologis), Jurnal Tadris, Vol.8, No.1, Juni, (2013). 